\title{
Adaptation of Lesson Study and Open Approach for Sustainable Development of Students’ Mathematical Learning Process
}

\author{
Sampan Thinwiangthong ${ }^{1}$, Maitree Inprasitha ${ }^{2}$, Suladda Loipha ${ }^{3}$ \\ ${ }^{1}$ Faculty of Education, Khon Kaen University, Khon Kaen, Thailand \\ ${ }^{2}$ Center for Research in Mathematics Education, Khon Kaen University, Khon Kaen, Thailand \\ ${ }^{3}$ Centre of Excellence in Mathematics, The Office of Higher Education Commission, Bangkok, Thailand \\ Email: sampan@kku.ac.th
}

Received July $7^{\text {th }}$, 2012; revised August $8^{\text {th }}$, 2012; accepted September $6^{\text {th }}, 2012$

\begin{abstract}
This research was aimed to analyze and develop Small-group Mathematical Communication (SMC) as Mathematical Learning Process (MLP) of the seventh grade students in Ban-beung-neam-beung-krainoon school for the school year 2008-2010 by adapting the Lesson Study and Open Approach which were innovations from Japan in order to be a context as well as guidelines for practice enhancing the students' MLP. The teaching experiment (Steffe \& Thomson, 2000) as a research methodology was used in designing the lesson plan, and studying students' MLP. The data were collected by using the video-audio recordings in classroom activities, video-stimulated interviewing the students, and interviewing the teacher. Data were also analyzed utilizing a video and protocol analysis. The research findings found that the students had SMC in mathematics classroom adapting Lesson Study and Open Approach. The students learned mathematics more meaningfully by themselves based on sharing mathematical ideas in order to create the shared meaning and leading to shared goal. They participated in SMC regularly. As a result, they developed a "habit of mind" which was led to a sustainable Mathematical Learning Process.
\end{abstract}

Keywords: Lesson Study; Open Approach; Mathematical Learning Process; Small-Group Mathematical Communication; Triad Feedback

\section{Introduction}

The major point of education is learning reform (Wasee, 2000). After the announcement of National Education Act 1999, the learning process was focused in Basic Education Curriculum 2001. However, the outcome of education reform from the first round in a previous decade did not show the emphasis of the learning in the classroom. Besides, the international study outcome-TIMSS (1999, 2003) and PISA (2003, 2006), found that Thai students had lower average score in every mathematics content than every national students' total average scores. Moreover, the findings of evaluation in the National Educational Quality by the Office of Standard Accreditation and Educational Quality Assessment (OSE) (second round during 2006-2010), found that most of the students could not reach the standard level in analytical thinking, synthetic thinking, and self-studying. Inprasitha (2006) stated that although there was an attempt of educational reform, most teachers still used the traditional way of teaching style focusing on the content without emphasizing on the students' MLP. Fernandez, Cannon, \& Chokshi (2003) suggested that the teachers needed to learn how to understand their students' MLP. The teacher, who understands his students' learning process, would have useful information in planning his lesson. Helping mathematics teachers to understand their students' MLP was based on an innovation for changing the traditional classroom into the classroom focusing on MLP and we need framework for understanding the students' MLP.

The Center for Research in Mathematics Education (CRME) has adapted both the Lesson Study and Open Approach from Japan in the mathematics classroom of Thailand since 2002
(Inprasitha, 2007). The Lesson Study (jugyou-kenkyu) came to be known around the world as a uniquely Japanese method of lesson improvement which is designed to facilitate the development of high quality lessons (Isoda, Stephen, Ohara, \& Miyakawa, 2007). The new approach of teaching professional development for enhancing the MLP was based on Lesson Study integrating an Open Approach (Loipha \& Inprasitha, 2004). In mathematics classroom using the Open Approach, the students' various ideas and thoughts would be discussed and developed mathematically through sophistication by their peer group and appropriate advice by the teacher. Thus, for the Open Approach, the class would share their common interest with the class which emphasizes mathematical discussion and communication (Nohda, 2000). Mathematical communication was the students' important MLP (Emori, 2005), especially, students' mathematical communication in small group working. However, most of the Thai mathematics teachers were not able to understand their students' SMC since the traditional classroom did not encourage students to express their thinking and feeling. Moreover, mathematics teachers did not know how to analyze SMC in classroom. Those problem issues prompted the researchers in determining the following research questions: how can we develop SMC as the students' sustainable MLP? And how can we analyze the students' SMC?

\section{The Application of Lesson Study and Open Approach in the Mathematics Classroom of Thailand}

Lesson Study is a cycle in which teachers work together to consider their long-term goals for students, bring those goals 
into life in actual "research lesson," and collaboratively observe, discuss, and refine the lessons (Lewis, 2002). Lesson Study was a teaching professional development which has been improved and used in Japan for 130 years (Shimizu, 2006). It was developed and applied in teaching professional development in many countries around the world, and being recognized as the most efficient technique to improve and develop the mathematics teaching. Furthermore, it was also a technique in developing the sustainable improvement of teaching (Lewis \& Perry, 2003). There were 8 steps of Lesson Study. These include: 1) Problem identification; 2) Class planning; 3) Class implementation; 4) Class evaluation and review of results; 5) Reconsideration of class; 6) Implementation of class based on reconsiderations; 7) Evaluation and review; and 8) Sharing of results (Stigler \& Hiebert, 1999 cited in Baba, 2007).

Loipha \& Inprasitha (2004) proposed that the Lesson Study was prominent including continuous and regular development focusing on classroom changes. According to this characteristic, some kinds of innovations to make changes were needed. These were carried-out by integrating into the topic to be developed continuously which was the approach of mathematics teaching model focusing on Open Approach. Therefore, new method of teaching professional development for enhancing the mathematics learning, was needed to be based on the approach of teaching improvement and development according to the steps of Lesson Study as development of teachers' collaboration in working by integrating into mathematics teaching model focusing on Open Approach which was teaching professional development in classroom level.

After Assistant Professor Dr. Maitree Inprasitha modified the Lesson Study in context of Thai class since 2002 until the present, there were 3 major phases of the modified Lesson Study. These in include: 1) Collaboratively Plan; 2) Collaboratively Do; and 3) Collaboratively See by integrating it with the Open Approach in order to implement every week in school (Inprasitha, 2008) as shown in Figure 1.

Figure 1 shows the integration of Lesson Study and Open Approach (Inprasitha, 2008) focus on development of students' mathematical thinking. The Open Approach included both the major matter for considering in each phase of Lesson Study, and teaching approach used by teacher in classroom teaching. As a teaching approach, it included 4 steps: These were: 1 ) Pose the open-ended problem; 2) Students' learning by them-

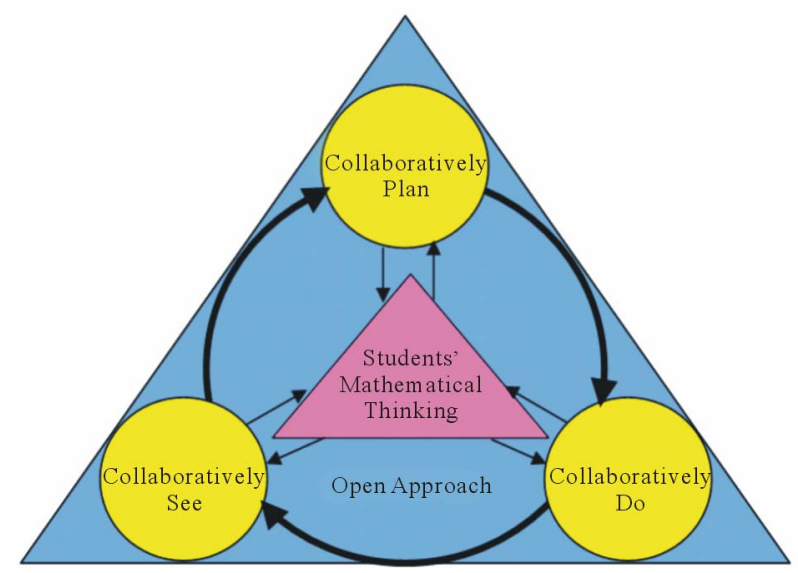

Figure 1.

The integration of lesson study and open approach. selves; 3) Whole class discussion; and 4) Summary through connection. Nohda (1993 cited in Inprasitha, 2004) stated that in mathematics classroom using Open Approach, the students' various ideas and thoughts would be discussed through sophistication by their peer group. Thus, for the mathematics classroom using Open Approach, it emphasizes mathematical discussion and communication.

According to the above mentioned, it leads to the first hypothesis that the integration of the Lesson Study and Open Approach in mathematics classroom could help the students to perform mathematical communication which is very important MLP, especially, the SMC. The students would obtain opportunity in creating the mathematical knowledge through SMC.

\section{Small-Group Mathematical Communication as Mathematical Learning Process}

Communication could be classified into educational system since the education was based on communication (Sierpinska, 1998; Emori, 2005). The students' mathematics learning based on mathematical communication included 3 characteristics which are as follows: Rigorousness, Economy, and Freedom in communicating the participants' thinking (Emori, 2005). These 3 characteristics determined "Mathematical", in "Mathematical Communication" which included opportunity that will occur during small group discussion.

Small group discussion is a communication among limited number of people in a place in order to accomplish Shared Goal of small group communication, Shared Meaning leading to Shared Goal as a factor classifying the group from gathering each person together, and the small group discussion from general conversation (Samovar, Henman, \& King, 1996). Shared Goal and Shared Meaning were important aspects of learning process of small group members.

The good lesson was developed based on students' natural thinking and feeling. We needed to know how the students think and feel in learning mathematics, emotional aspects should be focused on as well (Emori, 2005). However, the former studies of Mathematical Communication including Emori's (1993, 1997, 2005) findings, only cognitive aspect was studied. So, this study added the emotional aspect in SMC.

Inprasitha (2001) developed theoretical framework of students' emotional experience in mathematical problem solving, and explained emotional experience that: when human beings were facing the interruption, the findings of interruption was to stimulate physical arousal, and cognitive evaluation. We would use cognitive evaluation (such as cognitive evaluative schema) to make sense of interruption. The findings of cognitive evaluation would occur as different kinds of emotion such as surprise, confusion, enjoyment, or other kinds of emotion.

For this study, the theoretical framework of Emori (2005), Samovar et al. (1996) and Inprasitha (2001) were used in defining the SMC that: It was the students' conversation, discussion, argument including rigorousness, economy, and freedom of thought while they were working in small group in which they had their shared goal as well as shared meaning during solving mathematical problems together. Consequently, they changed their schema, and had emotional experience. The unit of analysis of SMC developed by the researcher called Triad Feedback (Thinwiangthong, Loipha, \& Pasjuso, 2010; Thinwiangthong, 2011) was as follows:

According to Figure 2, when the sender sent message 1 by 


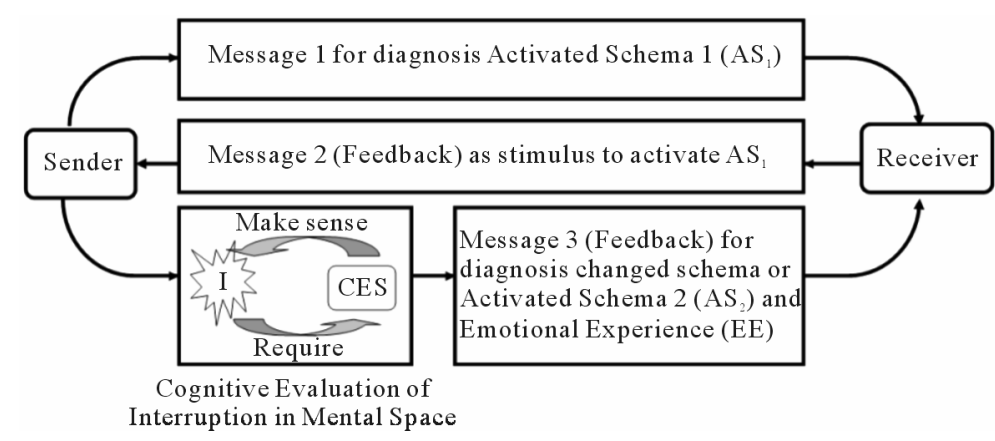

Figure 2.

Triad feedback: the unit of analysis of SMC.

conversation or facial expression, it is the evidences that the sender had Activated Schema $1\left(\mathrm{AS}_{1}\right)$. The receiver received message 1 , and sent message 2 as feedback, and stimulus stimulating the sender's $\mathrm{AS}_{1}$. So, the sender met the Interruption (I), and needed Cognitive Evaluative Schema (CES) in order to make sense for that Interruption. Then, the sender adjusted their mathematical idea or schema until it became the Activated Schema $2\left(\mathrm{AS}_{2}\right)$ and expressing the Emotional Experience (EE). This hypothetical model leads to the second hypothesis that Triad Feedback can be use to analyze both cognitive and emotional aspects in SMC.

\section{Research Objectives}

1) To develop the Seventh Grade Students' Small-group Mathematical Communication as Mathematical Learning Process in the Classroom using Lesson Study and Open Approach.

2) To analyze the Small-group Mathematical Communication of the seventh grade students in classroom using Lesson Study and Open Approach.

\section{Method}

This research study was conducted under the project for professional development of mathematics teachers through Lesson Study and Open Approach which has been implemented by CRME, Faculty of Education, Khon Kaen University since 2006. This study was conducted during 2009-2011. The teaching experiment based on Steffe \& Thomson' (2000) approach was used for designing the research method including the following details:

\section{Participants}

The participants were 8 seventh-grade students studying in Ban-beung-neam-beung-krai-noon school. Their age ranged from 12 - 13 years old. They are familiar with mathematics classroom adapting Lesson Study and Open Approach. They voluntarily participated in this study.

\section{Procedure}

\section{Document Analysis}

The researcher analyzed documents, research studies, and related theoretical framework of SMC including: Emori's (1993, 1997, 2005) theoretical framework of Mathematical Communication, Samovar et al. (1996) theoretical framework of Small Group Communication, and Inprasitha's (2001) theoretical framework of Emotional Experience in order to synthesize theoretical framework of SMC in classroom using Lesson Study and Open Approach.

\section{Participatory Observation}

The researcher participated as a member in Lesson Study team in conducting collaboratively plan, do, and see: to wit:

1) Collaboratively Plan, implemented every Tuesday Evening. The member team of Lesson Study including the teacher, participatory teacher, internship student, researcher, co-researcher, school coordinator, under monitoring and taking care of the director as well as experts of CRME, collaborated in developing the open-ended problems, designing the material and equipment, anticipating the students' mathematical ideas as well as response toward the open-ended problem, and understanding the students' SMC. In this step, the members' conversations were recorded using audio tape recorder.

2) Collaboratively Do, implemented during mathematics class organized by school in each week. The teacher implemented lesson plan in the classroom. Teaching was observed by the members of Lesson Study team. The objective of observation was to know the students' responses on the open-ended problem, SMC, the students' changes in mathematical ideas, and their emotional expression. In this step, the observer would take field note to record what were observed in the classroom. The classroom activities were recorded using a video tape recorder.

3) Collaboratively See, implemented in every Thursday evening. Every group member discussed the outcomes of teaching observation in different aspects including: the students' responses on open-ended problem, mathematical ideas, SMC, changes of mathematical ideas, and students' emotional expression. The sequence of reflection included: the teacher, internship students, participatory teacher, co-researcher, researcher, school coordinator, and experts of CRME. The objecttive of discussion was to improve the lessons. The members' conversation was recorded using an audio tape recorder.

\section{Video-Stimulated Interview}

After class, the researcher concluded the field note into issues regarding to SMC occurring in class, and studied the classroom video-tape to prepare the students' interview topics. For students' interview, the researcher turned on classroom video-tape for students to stimulate them to think back while they were participating in learning activities in class focusing on interviewing the SMC especially the students' thought and feeling occurring while they were performing SMC. 
Teacher and Participatory Teacher Interview

After completing the data collection of every lesson, the researcher interviewed teacher and participatory teacher including interview issues as: What do the classroom adapting Lesson Study and Open Approach, focus on or give value on? Are the students learning through classroom adapting Lesson Study and Open Approach, the same or different from students in traditional classroom? What does sustainable learning process mean? Does the classroom adapting Lesson Study and Open Approach able to develop the students' sustainable learning process? How?

\section{Video Analysis}

The researcher carefully analyzed video-tape by focusing on students' SMC. The students' thinking and feeling were satisfactory while they were participating in SMC by considering the occurrence regularly. Then, the hypothetical model was constructed to further explain the SMC. The researcher studied related theories and connected the theories with phenomenon in practice occurring in the classroom. As a result, the researcher understood both the components and process of students' SMC. Then, the researcher synthesized them as theoretical framework used to further study the SMC.

\section{Verification of Theoretical Framework}

The researcher investigated theoretical framework by collecting supplementary data of SMC, and using the synthetic theoretical framework in analyzing it to assure that it would be practical and more reliable.

\section{Instruments}

Instruments used to collect data were field note, video- and audio recorders. They were used for recording the activities in participatory observation (collaboratively plan, do, see), and interview sessions. Instrument used to analyze cognitive and emotional aspects in SMC, was the Triad Feedback-hypotheticcal model of SMC.

\section{Data Analysis}

For data analysis, video-tape was analyzed and written in analytic description to reveal details of the SMC. The researcher would like to show the samples of data analysis in order to reveal the details of SMC. These were as follows:

\footnotetext{
Topic: Relationship of two-dimensional geometry, and three-dimensional one.

Title: Magic Cube

Date and Place: 5th January 2011, 12:30-13:30 p.m. 7-grade Class.

Problem Situation: Let the students imagine that if the cube was cut and folded it into a flat figure as only one sheet. How many times do you need to cut it? And what figure it would be? Write figure as your imagination as much as possible.
}

After teacher pose open-ended problem on the board, and distributed single worksheet for students. The student read worksheet, and tried to think how many times they had to cut the edge of a cube. The teacher allows each student think about 5 minutes. Then, the students could speak with their nearby friend as following protocol which according to Figure $3\left(\mathrm{St}_{1}\right.$ : the first Student; $\mathrm{St}_{2}$ : the Second Student; $\mathrm{St}_{3}$ : the Third Student).

\begin{tabular}{|c|c|c|c|}
\hline Item 1 & $\mathrm{St}_{1}$ & $\begin{array}{l}\text { It's easy, five cut five times, is that right? } \\
\text { Cut here }\end{array}$ & Message 1 \\
\hline Item 2 & $\mathrm{St}_{2}$ & $\begin{array}{l}\text { (Show him worksheet drawing the figure } \\
\text { to } \mathrm{St}_{1} \text { ) }\end{array}$ & \multirow{3}{*}{ Message 2} \\
\hline Item 3 & $\mathrm{St}_{1}$ & $\begin{array}{l}\text { (Look at a figure drawn by } \mathrm{St}_{2} \text {, consider it, } \\
\text { and count the cut edges) } \\
\text { One, two, three. Folded into this figure. }\end{array}$ & \\
\hline Item 4 & $\mathrm{St}_{2}$ & $\begin{array}{l}\text { Is this figure right? (Pointing at one's } \\
\text { own figure. }\end{array}$ & \\
\hline Item 5 & $\mathrm{St}_{1}$ & Wait, wait, wait. & \multirow{5}{*}{$\begin{array}{c}\text { Cognitive } \\
\text { Evaluation of } \\
\text { Interruption } \\
\text { in } \mathrm{St}_{1} \text { 's } \\
\text { Mental Space }\end{array}$} \\
\hline Item 6 & $\mathrm{St}_{3}$ & $\begin{array}{l}\text { (Looking at figure pointed by } \mathrm{St}_{1} \text { ) } \\
\text { Is it right? }\end{array}$ & \\
\hline Item 7 & $\mathrm{St}_{2}$ & Don’t argue me. & \\
\hline Item 8 & $\mathrm{St}_{1}$ & One, two, three, four, five, six (try to think) & \\
\hline Item 9 & $\mathrm{St}_{3}$ & Seven (Looking at $\mathrm{St}_{1}$ 's face) & \\
\hline Item 10 & $\mathrm{St}_{1}$ & Hey! Seven times. & Message 3 \\
\hline
\end{tabular}

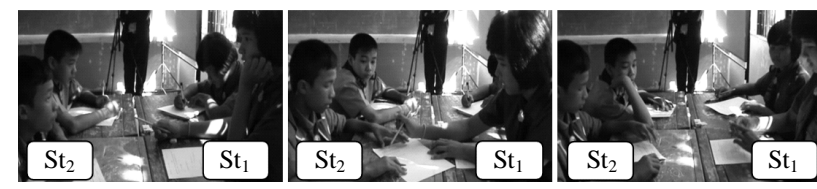

Figure 3.

The students' SMC while solving problem on magic cube.

The analysis of video as the above, was based on framework of Triad Feedback. $\mathrm{St}_{1}$ ' statement in Item 1 that "It's easy, five cut five times, is that right? Cut here." Could help the other students to understand that $\mathrm{St}_{1}$ cut the cube for five times as $\mathrm{St}_{1}$ 's intention. But, $\mathrm{St}_{2}$ wasn't certain. So, he handed in his worksheet written flat figure (see figure in protocol Item 4) for $\mathrm{St}_{1}$ to look at, and asked $\mathrm{St}_{1}$ in Item 4 that "Is this figure right?" $\mathrm{St}_{2}$ ' actions in handing in the worksheet including flat figure as well as asking, were messages turning back to $\mathrm{St}_{1}$. Then, $\mathrm{St}_{1}$ found different idea, and reviewed her own idea. $\mathrm{St}_{1}$ tried to think until she had her new mathematical idea which she never had this idea before. She spoke Item 10 that "Hey! Seven times". According to this communication, $\mathrm{St}_{1}$ and other students of this group, could be able to communicate as their intention by using concise message. In addition, it could help $\mathrm{St}_{1}$ to have new mathematical idea. The communication in this scene consisted of rigorousness, economy, and freedom in thinking of those who participated in communication.

Considering the goals of $\mathrm{St}_{1}$ and other students in the group, found that everyone had one's goal in finding the number of times for cutting the cube edges, which was a shared goal of $\mathrm{St}_{1}$ and other students. To accomplish the shared goal, $\mathrm{St}_{1}$ and other students in group communicated with each other until the shared meaning regarding to how many times one would cut the cube edges, was shown. In Item 1-4, other students had shared meaning with $\mathrm{St}_{1}$ that: one would cut the cube edges for 5 times. But, after $\mathrm{St}_{1}$ tried to think until she had new idea that: one needed to cut the cube edges for 7 times. The other students could understand that: how many times to cut the cube edges, were 7 times.

$\mathrm{St}_{1}$ presented his idea in Item 1 that: "It's easy, five cut five times, is that right? Cut here”, could be analyzed that $\mathrm{St}_{1}$ had 
schema in cutting the cube edges for 5 times, the flat figure $\left(\mathrm{AS}_{1}\right)$ as a sheet was occurred. Then, $\mathrm{St}_{2}$ handed in his own figure of how to cut the cube for $\mathrm{St}_{1}$ to see, and asked in Item 4 that: Is this figure right? $\mathrm{St}_{2}$ ' actions in handing in the worksheet including figure how to cut the cube as well as asking in Item 4 , were message 2 stimulating $\mathrm{AS}_{1}$. As a result, $\mathrm{St}_{1}$ met interruption (I) by saying that "Wait, wait, wait." $\mathrm{St}_{1}$ tried to think about her own idea which was duration $\mathrm{St}_{1}$ had cognitive evaluation by using cognitive evaluative schema (CES) to interpret the interruption. $\mathrm{St}_{1}$ considered the correctness as well as logic of the figure, and the number of cutting. The cognitive evaluation occurred in $\mathrm{St}_{1}$ 's mental space. Then, $\mathrm{St}_{1}$ ' schema was changed. Since $\mathrm{St}_{1}$ spoke with exciting voice in Item 10 that: "Hey! Seven times." When $\mathrm{St}_{1}$ said in Item 10, it was message 3 which could be analyzed to show $\mathrm{St}_{1}$ 's changed schema: the schema in cutting the cube for 7 times, the flat one as only one sheet $\left(\mathrm{AS}_{2}\right)$. In addition, $\mathrm{St}_{1}$ also expressed his emotional experience (EE) as the surprise, and excitement.

\section{The Findings from Interviewing the Teacher and Participatory Teacher}

The researcher interviewed teacher and participatory teacher regarding to students' sustainable learning process. The findings of interview were as follows:

From the Table 1, both the teacher, and participatory teacher revealed that a class using Lesson Study and Open Approach focusing on students' learning process, could help them think variously, feel more expressively, discuss and share their ideas, and perform SMC regularly. Consequently, this kind of classroom setting could be able to develop the students' habit of mind in solving the problems and sustainable learning process.

\section{Discussions}

Mathematics classroom adapting Lesson Study and Open
Approach was the problem solving classroom (Isoda et al., 2007). This new kind of classroom served to the expectation of educational reform in Thailand. Moreover, problem solving classroom was required in many countries around the world. Because it cultivated the quality citizens in the countries. This study showed some success in improving the traditional classroom to be the problem solving classroom.

This study incorporated emotional aspect into mathematical communication, especially, SMC. According to Hannula et al. (2004) stated that one important problem in the recent research on affect is the understanding of the interaction between affect and cognition. This study provided the teachers and researchers' intensive understanding of affect and cognition in SMC of students. However, Immordino-Yang (2011) suggested that cognitive, affective and social neuroscience have the potential to revolutionize educational theories of learning. This study does not incorporate neuroscience in the framework of SMC. It should be more recognized in the SMC future study.

\section{Conclusion}

According to the question: How can we develop SMC as the students' sustainable MLP? The research findings found that mathematics classroom adapting the Lesson Study and Open Approach, could develop the students' SMC. Since the students had opportunities to collaborate in solving the open-ended problem regularly, the students practiced thinking in problem solving through various solutions. They learned mathematics meaningfully by themselves based on sharing of mathematical ideas in order to create the shared meaning leading to the accomplishments of shared goals. As they perform SMC, they develop the "habit of mind" which lead to a sustainable Mathematical Learning Process.

According to the question that How can we analyze the students' SMC? The research findings found that the theoretical

Table 1.

The fidings from interviewing the teacher and participatory teacher.

\begin{tabular}{|c|c|}
\hline Teacher’s answers & Participatory teacher's answers \\
\hline \multicolumn{2}{|c|}{ Questions 1) What does the teacher who used Lesson Study and Open Approach focus on or value? } \\
\hline $\begin{array}{l}\text { I focused on students to have first-hand experience, real experiment and } \\
\text { practice, self-learning, and present their ideas. }\end{array}$ & $\begin{array}{l}\text { Students have different ideas. They are proud they think differently from their } \\
\text { friends. The class provides more freedom to solve problems. }\end{array}$ \\
\hline \multicolumn{2}{|c|}{$\begin{array}{l}\text { Questions 2) Do the students in classroom who adapt the Lesson Study and Open Approach, the same or different from the other students in traditional } \\
\text { classroom? How? }\end{array}$} \\
\hline $\begin{array}{l}\text { - The similar issue is: those who want to learn and know, could be able to } \\
\text { learn similarly both in the classroom adapting Lesson Study and Open } \\
\text { Approach, and in the traditional classroom. } \\
\text { - The different issue is: students in the classroom adapting Lesson Study } \\
\text { and Open Approach, are more expressive, better performance in the } \\
\text { presentation. They discuss on solving problem with their friends while in } \\
\text { the traditional classroom, the students ask their teacher only. }\end{array}$ & $\begin{array}{l}\text { - Classroom using these innovations, students could show divergent } \\
\text { thinking, solve problems by various solutions, and present their own } \\
\text { thinking. } \\
\text { - In traditional classroom, students have convergent thinking or one } \\
\text { solution only. }\end{array}$ \\
\hline \multicolumn{2}{|l|}{ Questions 3) What does sustainable learning process mean? } \\
\hline $\begin{array}{l}\text { The students could apply knowledge or learned techniques in other situations. } \\
\text { They are able to apply and expand it further. }\end{array}$ & $\begin{array}{l}\text { They could learn every place for the rest of their lives. They could solve } \\
\text { problems by themselves without place or time limitation. They could apply it. }\end{array}$ \\
\hline \multicolumn{2}{|c|}{ Questions 4) Could the classroom applying of Lesson Study and Open Approach, develop the students to have sustainable learning process? How? } \\
\hline $\begin{array}{l}\text { I think it does. But, it isn't quick. It depends on how much patience the } \\
\text { teacher has. We focus on process rather than product. We provide } \\
\text { instruments for students so that they would be able to apply those later. }\end{array}$ & $\begin{array}{l}\text { I think it does. Since it causes students to think differently and variously until } \\
\text { they could apply to solve problems in different situations. This kind of } \\
\text { classroom could develop sustainable learning process. }\end{array}$ \\
\hline
\end{tabular}


framework called Triad Feedback, synthesized by the researcher, could be used to analyze the students' SMC. It revealed the characteristics of Mathematical Communication, cognitive aspects as well as emotional aspects of SMC. This analysis aimed to understand the students' MLP so that the teachers or researcher would be able to utilize the students' thinking and feeling towards the lesson.

\section{Acknowledgements}

This research is (partially) supported by the Centre of Excellent in Mathematics, the Commission on Higher Education, Thailand, and Center for Research in Mathematics Education, Khon Kaen University, Thailand.

\section{REFERENCES}

Baba, T. (2007). How is lesson study implemented? In M. Isoda, M. Stephen, Y. Ohara, \& T. Miyakawa (Eds.), Japanese Lesson Study in Mathematics: Its Impact, Diversity and Potential for Educational Improvement (pp. 2-7). Singapore City: World Scientific Publishing Company.

Emori, H. (1993). The mechanism of communication in learning mathematics. In I. Hirabayashi, N. Nohda, K. Shigematsu, \& F.-L. Lin (Eds.), Proceedings of the 17th PME Conference (Vol. 2, pp. 230-237). Tsukuba: University of Tsukuba.

Emori, H. (1997). Mathematics communication. In T. Katsuro (Ed.), Rethinking Lesson Organization in School Mathematics (pp. 44-60). Japan: Japan Society of Mathematics Education.

Emori, H. (2005). The workshop for Young Mathematics Educations in Thailand 2005 building up the research agenda for the next 10 year, 2006-2015. Khon Kean: Khon Kean University.

Fernandez, C., Cannon, J., \& Chokshi, S. (2003). A US-Japan lesson study collaboration reveals critical lenses for examining practice. Teaching and Teacher Education, 19, 171-185. doi:10.1016/S0742-051X(02)00102-6

Hannula, M., Evans, J., Philippou, G., \& Zan, R. (2004). Affect in mathematics education-exploring theoretical frameworks. In M. J. Hines, \& A. B. Fuglestad (Eds.), Proceedings of the 28th Conference of the International Group for the Psychology of Mathematics Education (pp. 107-136). Bergen: Bergen University College.

Immordino-Yang, M. H. (2011). Implication of affective and social neuroscience for educational theory. Educational Philosophy and Theory, 43, 98-103. doi:10.1111/j.1469-5812.2010.00713.x

Inprasitha, M. (2001). Emotional experience of students in mathematical problem solving. Doctoral Dissertation, Tsukuba: University of Tsukuba.

Inprasitha, M. (2003). Teaching by using open approach in mathematics classroom of Japan. KKU Journal of Mathematics Education, 1, $1-17$.

Inprasitha, M. (2006). Open-ended approach and teacher education. Tsukuba Journal of Educational Study in Mathematics, 25, 169-178.

Inprasitha, M. (2007). Lesson study in Thailand. In M. Isoda, M. Stephens, Y. Ohara, \& T. Miyakawa (Eds.), Japanese Lesson Study in Mathematics: Its Impact, Diversity and Potential for Educational
Improvement (pp. 188-193). Singapore City: World Scientific Publishing Company.

Inprasitha, M. (2008). A research report titled "model of students" mathematical thinking development by lesson study and open approach. Khon Kaen: Center for Research I Mathematics Education.

Isoda, M., Stephen, M. Ohara, Y., \& Miyakawa, T. (2007). Japanese lesson study in mathematics: Its impact, diversity and potential for educational improvement. Singapore City: World Scientific Publishing Company.

Lewis, C. (2002). Lesson study: A handbook of teacher-led instructional change. Philadelphia, PA: Research for Better Schools.

Lewis, C., \& Perry, R. (2003). Lesson study and teachers knowledge development: Collaborative critique of a research model and methods. Annual Meeting of the American Educational Research Association 2003. Chicago: AERA.

Loipha, S., \& Inprasitha, M. (2004). Development of new teaching profession for enhancing mathematical learning. KKU Journal of Mathematics Education, 1, 18-28.

Nohda, N. (2000). Teaching by open-approach method in Japanese mathematics classroom. In T. Nakahara, \& M. Koyama (Eds.), Proceedings 24th of the Conference of the International Group for the Psychology of Mathematics Education, 1, 39-53.

OECD (2004), Learning for tomorrows world-First results from PISA 2003. Paris: OECD Publication.

Samovar, L. A., Henman, L. D., \& King, S. W. (1996). Small group process. In R. S. Cathcart, L. A. Samovarm, \& L. D. Henman (Eds.), Small Group Communication: Theory \& Practice. Dubuque: Times Mirror Higher Education Group.

Shimizu, S. (2006). Professional development through lesson study: A Japanese case. APEC International and Learning Mathematics through Lesson Study, Khon Kaen.

Sierpinska, A. (1998). Three epistemologies, three views of classroom communication: Constructivism, sociocultural approaches, interactionism. In H. Steinbring, A. Sierpinska, \& M. G. Bartolini-Bussi. (Eds.), Language and Communication in the Mathematics Classroom (pp. 30-62). Reston, VA: NCTM.

Steffe, L. P., \& Thomson, P. W. (2000). Teaching experiment methodology: Underlying principles and essential elements. Mahwah, NJ: Lawrence Erlbaum Associates.

Stigler, J., \& Hiebert, J. (1999). The teaching gap-Best ideas from the world's teachers for improving education in the classroom. New York: The Free Press.

Thailand PISA Project, Institute for Promoting the Mathematics and Technology Teaching (2010). The findings of PISA 2009 evaluation, reading, mathematics, and science: Conclusions for administration. Bangkok: Aroon Printing.

Thinwiangthong, S., Loipha, S., \& Pasjuso, S. (2010). Triad feedback: Unit of analysis of small-group mathematical communication to understand mathematical learning process. In Y. Shimizu, Y. Sekiguchi, \& K. Hino (Eds.), Proceeding of the 5th East Asia Regional Conference on Mathematics Education. Tokyo: Inamoto Printing.

Thinwiangthong, S. (2011). Verification of triad feedback-The unit of analysis of small-group mathematical communication. In B. Ubuz (Ed.), Proceeding of the 35th International Conference on Psychology of Mathematics Education, Ankara.

Wasee, P. (2000). Learning reform: The Students are the most important. Bangkok: The Office of National Education Commission. 